\title{
Procheirisis: Porphyry Sent. 16 and Plotinus on the similes of the waxen block and the aviary*
}

\author{
Robbert van den Berg \\ Leiden University, Leiden, The Netherlands \\ r.m.van.den.berg@hum.leidenuniv.nl
}

\begin{abstract}
This paper studies Sentence 16 of Porphyry's Pathways to the Intelligible. It is argued that it should be understood against the background of Plotinus' discussions of the similes of the waxen block and the aviary from Plato's Theaetetus. The first part of the paper concentrates on Plotinus' reception of these similes. In the second part of the paper Plotinus' discussions of the two similes are used to shed

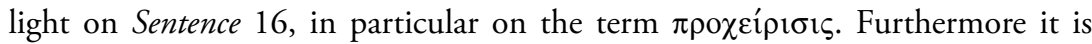
argued that Porphyry does not reject Plotinus' claim that, pace Aristotle, intellection does not require imaging.
\end{abstract}

\section{Keywords}

Theaetetus; procheirisis; phantasia; sense-perception; intellection

\section{Introduction: Porphyry Sent. 16}

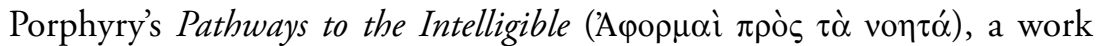
which presents the essential points of Plotinus' philosophy in a concise manner, is as important for the study of Neoplatonism as it is opaque. Fortunately, the recent publication of an edition of this text with translations in both French and English, introductory studies, and elaborate commentaries in two volumes by a team of renowned scholars affiliated with the Unité Propre de Recherche Scientifique 76 of the French CNRS

\footnotetext{
*) A previous version of this paper was read at the ISNS 2009 conference in Krakow. I am grateful to the participants and anonymous referee of the journal for their helpful remarks and criticism.
} 
has greatly improved our understanding of this text. ${ }^{1}$ The present paper on

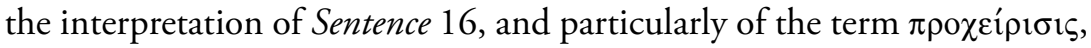
stands on the shoulders of this giant project.

According to the late J. Pépin, the scholar who is for the most part responsible for the commentary on Sent. 16, the sentence is primarily about sensation, which Porphyry here discusses in relation to intellection. ${ }^{2}$ I shall now first give the corrupted Greek text together with the English translation by John Dillon. ${ }^{3}$

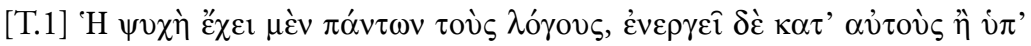

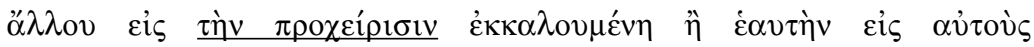

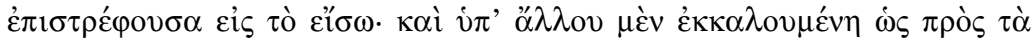

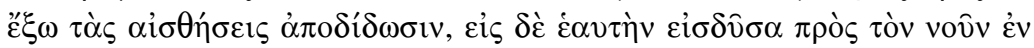

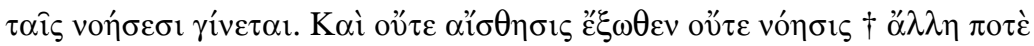

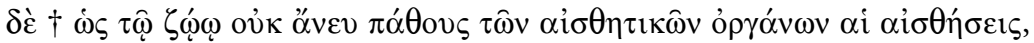

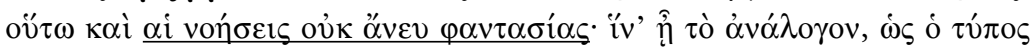

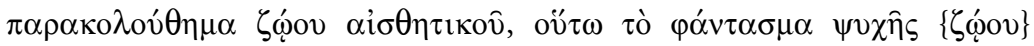

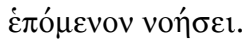

The soul contains the reason-principles of all things, but it acts on them (only) by either being provoked to actualize them by some external stimulus or through directing itself towards them inwardly. And when it is provoked by an external influence, as it were outwards, it produces sense-perception, while when it withdraws into itself in the direction of intellect, it finds itself in the process of intelligizing. And neither sense-perception, generated, as it is, externally, nor intellection ${ }^{* * *}$; but even as in the living being sense-

\footnotetext{
1) Brisson (2005).

2) Brisson (2005) 430 and 457. Even though the commentary is the result of a collective project, the contributions of each scholar are explicitly noted, especially since the various contributors do not necessarily agree with each other, cf. Brisson (2005) 5-6.

3) For the French translation, see Brisson (2005) 315-316: Lâme possède de toutes choses les raisons, mais elle agit d'après elles soit en étant appelée par autre chose à les prendre en mains, soit en se retournant soi-même vers elles, vers l'intérieur: si elle est appelée par autre chose comme en direction des objects extérieurs, elle produit les sensations, mais si elle a pénétré en soi-même en direction de l'intellect, elle se trouve dans les intellections. Ainsi il n'y a pas de sensation qui vienne de l'extérieur, non plus que d'intellection. $\dagger \ldots \dagger$ De même que, pour le vivant, sans que soient affectés les organes sensoriels, les sensations n'ont pas lieu, de même aussi les intellections n'ont pas lieu sans imagination; c'est afin qu'existe la proportion: de même que l'empreinte est l'accompagnement du vivant dans sa fonction sensorielle, de même l'image, dans l'âme, suit l'intellection.
} 
perceptions do not occur without affections of the sensory organs, so also intellections do not occur without imaging; so that the analogy may be: as the (external) impression is an accompaniment to a living thing experiencing a sense-perception, so the mental image in the case of the soul a consequence of intellection (trans. Dillon in: Brisson (200) 799).

Pépin calls attention to two problematic elements that have been underlined in the text and italicized in the translation. First, at the beginning, there is the riddling word $\pi \rho 0 \chi \varepsilon i$ proıs. ${ }^{4}$ As Pépin explains, Porphyry uses the term in order to draw a distinction between merely having ('̌ $\chi \varepsilon 1 v$ ) rea-

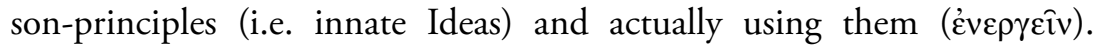
Indeed, as Pépin, perusing a great number of texts from Plotinus down to

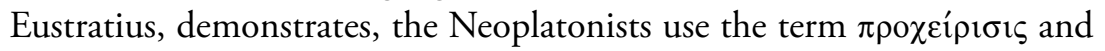
its cognates to refer to the active exercise of knowledge ('agir') as opposed to passive possession ('posseder') of it.' It recalls Aristotle's concept of double entelecheia, which Aristotle illustrates by contrasting the possession

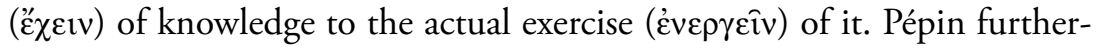

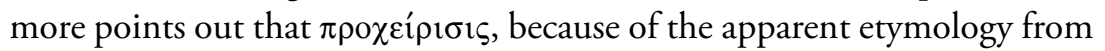
$\chi \varepsilon i \rho$ ('hand'), is a metaphorical expression, rendered in the French translation as 'prendre en mains'. John Dillon, by contrast, in his English translation, resists the translation 'to take in hand', because it does not "quite catch the sense" ${ }^{6}$ Below, we shall see that the metaphor is anything but a dead one.

A second problematic aspect of this text is that Porphyry claims, or seems to claim, that "intellections do not occur without imaging". HansRudolph Schwyzer has argued that Porphyry here parts way with his teacher Plotinus. Plotinus had explicitly rejected Aristotle's idea that intellection requires imaging, the very idea that Porphyry here seems to accept. ${ }^{7}$

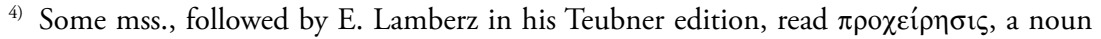
derived from the unattested verb * $\pi \rho \circ \chi \varepsilon \imath \rho \varepsilon \omega$, which supposedly means "to pass something to some-one else." Pépin in Brisson (2005) 458-459 rightly, as I shall argue in this paper,

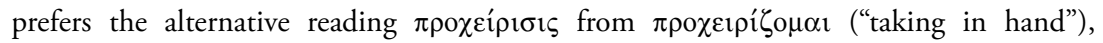
instead.

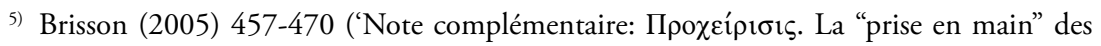
raisons').

6) Brisson (2005) 799 n. 25.

7) Schwyzer (1974) 246-248. The relevant texts are Aristotle de An. III 7, esp. 431a16-17 and b2 and Plotinus Enn. I 4 [46] 10, 17-21, well discussed by Pépin in Brisson (2005)
} 
Pépin, for his part, argues that we have to assume that Porphyry too rejects this Aristotelian idea and that he did so in the now badly corrupted preceding section of the text. ${ }^{8}$

In this paper, I shall argue (1) that the term $\pi \rho \circ \chi \varepsilon i p i \sigma i s$ originates from the aviary simile from Plato's Theaetetus and that it derives its meaning from Plotinus' interpretation of this simile in combination with another simile from the Theaetetus, that of the waxen block and (2) that Plotinus' interpretation of these helps us to better understand Sentence 16 including the problematic second part of Sentence 16. More in particular, I shall argue that the claim that intellections do not occur without imaging is ultimatily sound Plotinian doctrine, instead of a case of what Schwyzer called 'Unplotinisches' in Porphyry's 'A $\varphi$ op $\mu \alpha$ í. I shall now first briefly recall Plato's similes of the waxen block and the aviary, next I turn to Plotinus' interpretation of these, and finally I shall discuss how Plotinus' interpretation casts light on Porphyry's Sentence 16.

\section{The Similes of the Waxen Block and Aviary in Plato's Theaetetus}

In a famous passage from the Theaetetus, Socrates raises the issue of how false judgement is possible. In the following paraphrase, I shall especially highlight those elements that are of particular interest for my present purpose. The first thing to note is that by way of introductory remark Socrates describes the activity of judging as a dialogue that takes place

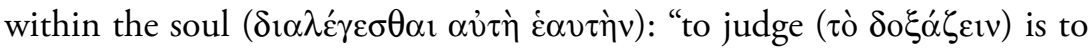

447-449, cf. also the discussion by C. D’Ancona in Brisson (2005) 210-211. Lautner (2007) 87 indeed assumes that in Sent. 16 "Porphyry makes an Aristotelian point in so far as he claims that thinking does not occur without phantasia".

8) See Brisson (2005) 455-457. Pépin argues that in the last lines we are dealing with two analogies instead of one. The first analogy holds that (1a) even as in the living being senseperceptions do not occur without affections of the sensory organs, so also (1b) intellections do not occur without imaging. The second analogy holds that (2a) as the imprint is an accompaniment to a living thing experiencing a sense-perception, (2b) so the mental image in the case of the soul a consequence of intellection. Pépin argues that both Plotinus and Porphyry reject analogy (1) because they find fault with (1b), while they accept (2). However, the final sentence, Pépin' second analogy, is introduced with the words "so

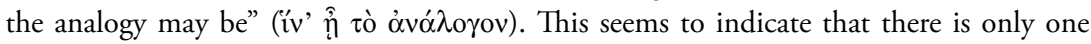
analogy, which is drawn as some sort of conclusion of the previous discussion. 
make a statement $(\lambda o ́ \gamma o \varsigma)$, and a judgement is a statement which is not addressed to another person or spoken aloud, but silently addressed to oneself". ${ }^{9}$ In a first attempt to explain how false judgement works, Socrates next comes up with the simile of the waxen block. In our soul we have, so to speak, a block of wax. Socrates continues:

[T.2] We make impressions upon this of everything we wish to remember

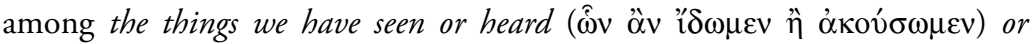

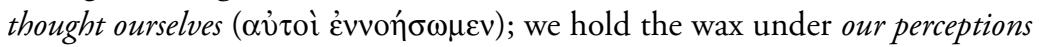

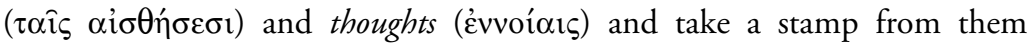
$(\dot{\alpha} \pi \circ \tau v \pi \circ \hat{0} \sigma \theta \alpha \mathrm{l})$ in the way in which we take the imprint of signet rings

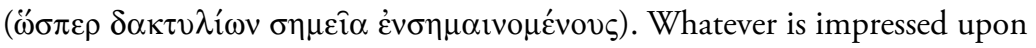
the wax we remember and know so long as the image remains in the wax (Plato Tht. 191d5-10; trans. Levett).

Socrates uses this model to explain false judgements in those cases in which one mistakes someone for someone else, e.g. when I see Theaetetus, whom I know, but mistake him for his teacher Theodorus, whom I also know, due to the fact that I see Theaetetus in the distance. In that case, I wrongly connect my visual perception of the man in the distance to the imprint that I have in my soul of Theodorus.

Socrates next criticizes this explanation of false judgement because it only accounts for those cases of false judgement in which perception is involved. There are, however, cases of false judgement that do not involve perception. One may, for example, wrongly believe that five and seven make eleven. In order to explain this case of false judgement, Socrates distinguishes between two ways in which one may have knowledge. One may either have knowledge in the sense of having acquired knowledge and possess it latently, or have knowledge and actively use it. To illustrate his point, Socrates compares the human soul to an aviary. When we were children, our birdcages were empty. Next we started filling it with birds, i.e. with pieces of knowledge. The birds that fly around in the aviary stand for the knowledge that we possess latently. Activating this knowledge is comparable to going into the aviary and grasping one of the birds. What happens when we falsely judge that five and seven makes eleven is that, while we intend to grasp the bird 'twelve', we actually grasp the bird

9) Tht. 190a4-6 (trans. Levett). 
'eleven'. Note how exactly Socrates refers to this activity of grasping the birds that fly around in the birdcage:

[T.3] Then using our image of possessing and hunting for the pigeons, we shall say that there are two phases of hunting: one before you have possession, in order to get possession, and another when you already possess in

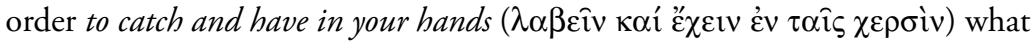
you have previously acquired. And in this way even with things you learned and got the knowledge of long ago and have known since, it is possible to learn them—-these same things_-all over again. You can take up again and 'have' that knowledge of each of them which you acquired long ago but had

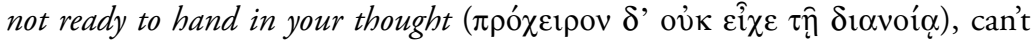
you? (Plato Tht. 198d1-8; trans. Levett)

The term $\pi \rho \circ \chi \varepsilon i p ı \sigma ı$ obviously originates from this passage. The translation 'to take in hand' captures the image behind this term perfectly well and is to be preferred over Dillon's somewhat bland 'to actualize', especially since, as we are about to see, Plotinus, whose philosophy Porphyry here presents, was well aware of its origin. It now remains to be seen what for Plotinus and Porphyry this 'taking in hand' involves.

Before we can turn to the Neoplatonist interpretation of this image, though, one, seemingly innocent, detail of the waxen block simile needs to be mentioned. Socrates (T.2) distinguishes between two types of imprints. On the one hand there, are the imprints of the things that we have perceived through the senses, e.g. things seen and heard, and, on the other hand, we have imprints of the things we think ourselves. In the former case we hold the wax of our soul under our perceptions ( $\alpha i \sigma \theta \eta \dot{\sigma \varepsilon \imath \varsigma}$ ) in the other case under our thoughts ('zvvoral). Francis Cornford, in his classical commentary on the Theaetetus, suggests that this somewhat puzzling remark looks forward to the numbers of the aviary simile, which after all, we apparently do not perceive as such. ${ }^{10} \mathrm{He}$ furthermore observes that it may surprise a Platonist to read that our knowledge of the number twelve does not derive from our recollection of the Form Twelve, i.e. the Platonic theory of knowledge as anamnesis, but from some imprint in the memory-tablet. As we shall now see, Plotinus, a Platonist reader of Plato if there ever was one, does indeed try to square the Platonic theory of knowledge as anamnesis with this simile that compares our knowledge with imprints in wax.

10) Cornford (1934) 122. 


\section{Plotinus on the Similes of the Waxen Block and the Aviary}

\subsection{The Waxen Block (Enn. V3 [49] 2-3)}

Before dealing with the simile of the aviary and the 'taking-in-hand' of pieces of knowledge, let us first look at Plotinus' interpretation of the waxen block simile as we find it in Enn. V 3 [49] 2-3. In this passage Plotinus describes how the soul perceives both what is outside it in the material world and what is above it in the intelligible realm. Both categories of things cause 'imprints' ( $\tau$ ' $\pi \mathrm{o})$ ). In our passage, Plotinus explains that in the case of material objects the perceptive part of the soul perceives the affections in the body ( $\dot{\varepsilon} v \tau \hat{\emptyset} \sigma \dot{\omega} \mu \alpha \tau \imath \pi \alpha \theta \dot{\eta} \mu \alpha \tau \alpha)$, rather than objects in the outside world themselves. These sensory data next become the object of mental processes:

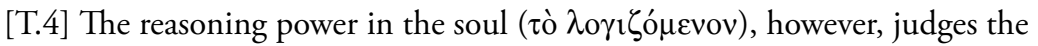
mental images ( $\varphi \alpha v \tau \alpha \sigma \mu \alpha \dot{\tau} \tau \omega v)$ that originate from sense-perception by combining and dividing them (Enn. V 3 [49] 2, 7-9).

Above we have seen that in the Theaetetus, Socrates distinguishes between the imprints that result from sense-perception and those that result from thoughts, e.g. thoughts of numbers. As we then observed, a Platonist might be inclined to understand these as imprints of Forms, not of some quality in the physical world. This is indeed how Plotinus appears to understand the simile of the waxen block for he continues directly after the text just quoted:

[T.5] ... and, as for the things which come from Intellect, soul observes them

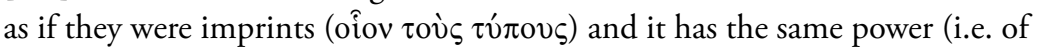
combining and dividing, RvdB) in regard to these (Enn. V 3 [49] 2, 9-11).

There are, then, in the soul two types of mental images or 'imprints', one coming from above, from the Intellect, another from the senses. This is Plotinus' famous theory of the 'double' phantasia. ${ }^{11}$

Plotinus considers sense-perception proper to consist not in passively receiving sensory data in the soul, but rather in the activity of judging these data. In Enn. V 3 [49] 2, Plotinus describes this process of judgment

\footnotetext{
11) For texts by Plotinus and other Neoplatonists and secondary literature on 'double phantasia', cf. Sorabji (2004) 63-65.
} 
in accordance with the simile of the waxen block in terms of correctly

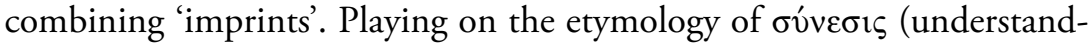
ing) from $\sigma u v i$ in (bringing together), Plotinus refers to this process of

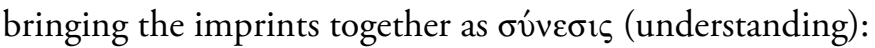

[T.6] And the soul continues to acquire understanding as if by recognizing the new and recently arrived imprints and fitting them to those which have long been within: this process is what we should call the 'recollections' of the soul (Enn. V 3 [49] 2, 11-14; trans. Armstrong slightly adapted).

In the case of sense-perception, the two types of imprints that we distinguished above come into play, as appears from Plotinus' analysis of what happens when we see Socrates.

[T.7] Well, then, sense-perception sees a human being and gives its imprint ( $\left.v^{\prime} \pi \mathrm{ov}\right)$ to discursive reason. What does reason say? It will not say anything yet, but only knows, and stops at that; unless perhaps it has a dialogue with

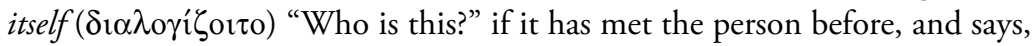
using memory to help it, that it is Socrates.... and if it says whether he is good, its remark originates in what it knows through sense-perception, but what it says about this it has already from itself, since it has a norm of the

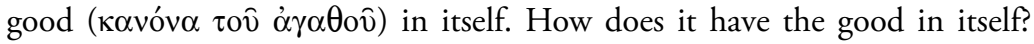
Because it is like the good, and is strengthened for the perception of this kind of thing by Intellect illuminating it: for this is the pure part of the soul and receives the traces (' $' \chi \chi \vee \eta \eta)$ of Intellect coming down upon it (Enn. V 3 [49] 3, 1-12; trans. Armstrong slightly adapted).

First, note that Plotinus, in keeping with the Theaetetus, explicitly imagines that the soul, when it judges the incoming imprints, engages in some kind of dialogue with itself. This dialogue involves the actual exercise of knowledge that the soul previously latently possessed. Note furthermore that Plotinus here contrasts our recognition of Socrates as being Socrates with our recognition of Socrates as being a good man. When we recognize the man whom we see as Socrates we connect the imprint of the visual appearance of Socrates to previous imprints of visual appearances of Socrates, i.e. we bring together two imprints that originate from senseperception. In the case that we recognize Socrates as a good man, however, we fit the imprint caused by our present perception of the good man 
Socrates to our notion of goodness, which originates from Intellect. Plotinus here calls it an 'i $\chi v 0 \varsigma$, a trace, or footprint, left behind by Intellect. The word derives once more from the Theaetetus, where Socrates uses it as syn-

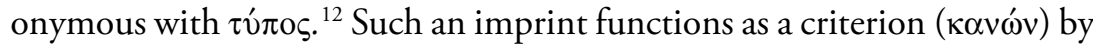
means of which we judge the newly arrived imprints. They are the logoi to which Porphyry refers in Sentence 16, the innate reason-principles that the soul has and which derive from the Intellectual Forms contained in Intellect. When the soul enters into a conversation with itself in order to judge the incoming sensory data, it activates these reason-principles, i.e. it takes them in hand as Sentence 16 puts it. ${ }^{13}$

\subsection{The Aviary (Procheirisis)}

Since in the account of sense-perception in Enn. V 3 [49] 2-3 the term $\pi \rho 0 \chi \varepsilon i p i \sigma i s$ or its cognates does not occur, we have to look elsewhere in the Enneads to study this aspect of Plotinus' understanding of the simile of the aviary in greater detail. As we shall see, it entails more than just exercising knowledge in the Aristotelian sense.

To start with, from the discussion so far one might be tempted to

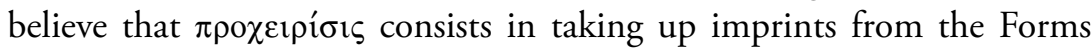
that lie passively in the soul as pieces of unexercised knowledge. This, however, is not the case. As has been pointed out in various recent studies, Plotinus severely criticizes the Stoic account according to which a material soul undergoes physical imprints. ${ }^{14}$ This is, among other texts, brought out clearly in Enn. III 6 [26] in which Plotinus argues that

12) Plato Tht. $193 \mathrm{c} 4$.

13) Lautner (2007) 87 argues that the $\lambda$ ó $\gamma 0$ in Sent. 16 "pertain both to the Ideas directly, and to the forms of physical bodies that acquire these forms from the Ideas. In the first case, the soul turns inward to examine them, in the second case it turns outward and draws on sense-perception to get acquainted with sensible forms." In this paragraph and the next, I try to show that in both cases-i.e. in the case of introspection and in that of sense-perception-the $\lambda$ óror are the same, i.e. emanations of the Forms in the human soul. Barnes (2008) 150-151, when reviewing Lautner (2007), too concludes that the $\lambda$ ó $\gamma o t$ in the case of sense-perception refer to innate Ideas.

14) On Plotinus' criticism of the Stoic account in relation to the Theaetetus, see the instructive discussion by Bonazzi (2005) and D'Ancona (2007), whose analysis of Plotinus' concept of memory as activily looking towards the reason-principles informs the present discussion. 
bodiless entities, such as souls, do not undergo affections $(\pi \dot{\alpha} \theta \eta)$. If the soul would indeed receive imprints from the Forms, it would undergo affections. In chapter two of the treatise, Plotinus describes what happens when the soul pays attention to its $\lambda$ óros, i.e. the sum of all reason-principles that originate from Intellect as we have just seen. Plotinus writes:

[T.8] Now listening to logos is like seeing, not receiving a shape, but seeing and being in act when the seeing takes place. For just as sight, which has both a potential and an actual existence, remains essentially the same [when it is potential and when it is actual], and its actuality is not an alteration but it simultaneously approaches what it has, and is it in knowing it and knows without being affected; in the same way, too, the reasoning part is related to Intellect and sees, and this is the power of intellection; there is no stamp impressed on it (viz. the soul, RvdB) internally, but it has what it sees and in another way does not have it; it has it by knowing it, but does not have it in that something is put away in it from the seeing, like a shape in wax. And we must remember that memories too, in our account of them, do not exist because things are put away in our minds, but the soul awakes the power [of memory] in such a way as to have what it does not have. (Enn. III 6 [26] 2, 32-44; trans. Armstrong slightly adapted).

Thus, the intelligible Forms do not leave any imprints in the soul, as the Theaetetus may seem to suggest. Note that even in Enn. V 3 [49], where Plotinus under the influence of the Theaetetus talks about imprints, he says that the soul observes "the things which come from Intellect" "as if they were imprints" (T.5), not that they are imprints. ${ }^{15}$ The point is that imprints once they have been made remain in the wax, whereas the "things that come down from Intellect" remain in the soul only as long as the soul actively looks at these.

In Enn. V 3 [49] 2 and 3 (T.5 and T.7) Plotinus talks about the imprints against which we judge sense-perceptions as coming from Intellect. In T.8, however, he says that we listen to logos, while Porphyry (T.1) talks about the taking in hand of logoi. What are these? The $\lambda$ ó $\gamma$ or are

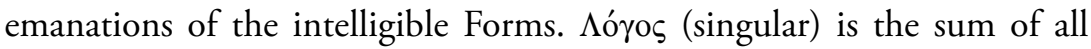
these $\lambda$ ó $\gamma o r$ together. As such it is an emanation of Intellect, which itself

15) As observes D’Ancona (2007) 74. 
consists of all intelligible Forms. ${ }^{16}$ For this reason, Plotinus calls it a 'sort of intellect' of the soul. ${ }^{17}$ Since this is only a second-rate intellect it is not, immediately at least, able to contemplate the $\lambda$ ó $\gamma o u$ in the unified manner in which Intellect contemplates the Forms. For that reason, soul produces images of these $\lambda$ ó $\gamma$ or so that it may study these logoi, which it possesses, discursively. ${ }^{18}$ In Enn. III 8 [30] 6-a text to which Pépin rightly draws

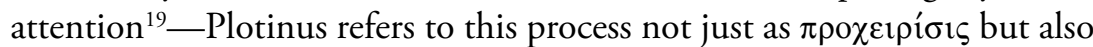

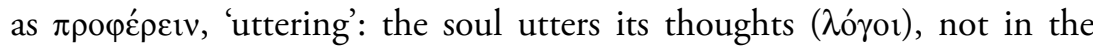
sense that the philosopher literally speaks out his thoughts aloud, but rather that it articulates its own reason-principles to itself. ${ }^{20}$ In a similar vein, other Neoplatonists, including Porphyry, talk about the 'projecting',

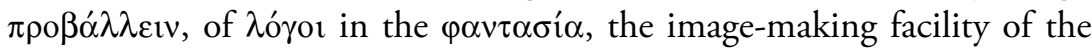

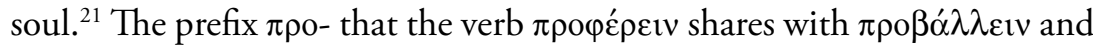

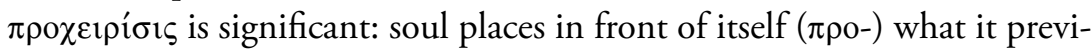
ously had inside so that it may inspect it. Enn. III 8 [30] is about contemplation of higher realities. Soul discursively studies the projections of the logoi in order to grasp the content of its logos only in order to proceed "to become in other things", i.e. to ascend to the intelligible realm. ${ }^{22}$

So far we have not yet found a passage in which Plotinus discusses

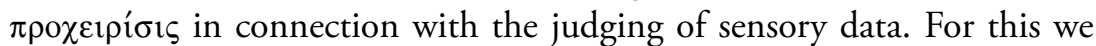
have to turn to Enn. I 1 [53] 9. There, Plotinus explains what happens in the case of the 'thinking of falsities', or at least what is called thus, i.e. the

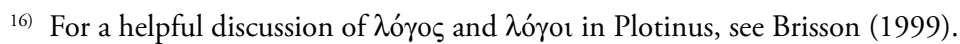

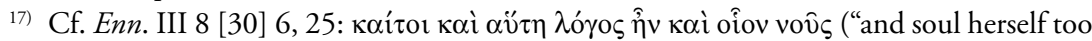
was a logos and a sort of intellect").

18) Enn. III 8 [30] 6, 26-29: "For it (i.e. the logos or intellect of soul, $\mathrm{RvdB}$ ) is not full, but has something wanting in relation to what comes before it; ... what it utters ( $\left.\pi \rho \circ \varphi \varepsilon^{\prime} \rho \varepsilon 1\right)$, it utters because of its deficiency, with a view of examining it, trying to learn thoroughly what it possesses." (trans. Armstrong).

19) Brisson (2005) 460-461.

20) Enn. III 8 [30] 6, 21-25: "The soul, then, when it has become akin and disposed accord-

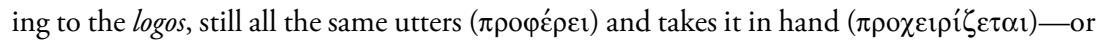
it did not possess it primarily-and learns it thoroughly and by taking it in hand

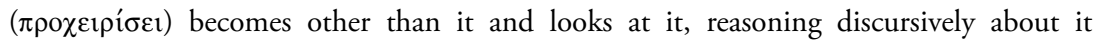

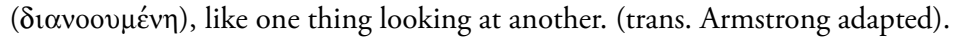

21) On this process of projection in Neoplatonic psychology both in Porphyry and later authors, cf. Sorabji (2004) 68-70 for texts and discussion.

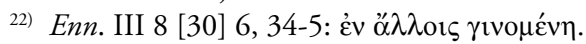


phenomenon that the similes from the Theaetetus try to explain. ${ }^{23}$ Plotinus denies that we actually think falsities. What in fact happens is that we receive a mental image ( $\varphi \alpha v \tau \alpha \sigma i \alpha)$, stirred up by desire or passion, which we do not subject to the judgment (кpí⿴\zh11s) of discursive reasoning, just as in sensation we may see falsely before discursive reasoning has judged the impression it receives. ${ }^{24}$ So here again, sense-perception is understood as a sort of judgment. Plotinus continues that in such cases we do not touch "the intelligible in Intellect, or rather in us". ${ }^{25}$ With "the intelligibles in us", Plotinus refers to the $\lambda$ ó ${ }^{\prime}$, , for in the previous chapter he had explained that we possess the Forms in two ways: in Intellect to the extent that we posses Intellect itself (a reference to Plotinus' doctrine of the undescended soul) and in our soul, where they are unfolded and separated, hence the $\lambda$ ó ${ }^{2}{ }^{26} .{ }^{26} \mathrm{He}$ continues: "for it is possible to have these and not have them in hand". ${ }^{27}$ When, however, discursive reasoning does judge the imprints produced by sensation, it simultaneously contemplates the Forms ${ }^{28}$ All this strongly recalls the Theaetetus, as has indeed been noted by two recent commentators of this text. ${ }^{29}$

To sum up: Plotinus assumes that the similes of the waxen block and the aviary are about the double function of $\lambda$ órot. On the one hand the soul uses them in the process of sense-perception as criteria against which it judges incoming sensory information. On the other hand, soul studies them in their own right as copies of the Forms. Since these $\lambda$ óror constitute the intellect of the soul (its logos), while the aforementioned activities take place in the discursive part of the soul—as appears from the fact that this part of the soul engages in a conversation with itself-soul needs to take the $\lambda$ óror down from the level of intellect to that of discursive reasoning. This may be described as the 'uttering', 'projecting', or 'taking in

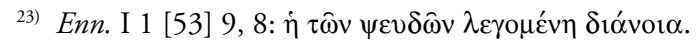

24) Enn. I 1 [53] 9, 8-12.

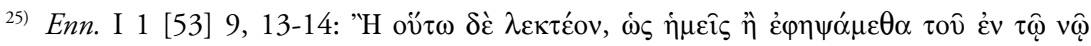

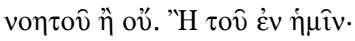

26) Enn. I 1 [53] 8, 6-8.

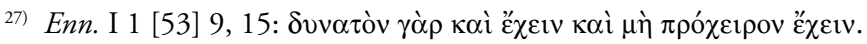

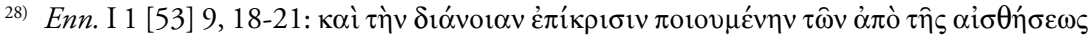

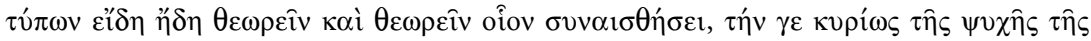
$\dot{\alpha} \lambda \eta \theta$ ov̂s $\delta$ ióvor $\alpha v$.

29) See the extensive discussion in Aubry (2004) 263-272 and Marzolo (2006) 150-161. 
hand' of these and results in images in the phantasia, the same faculty in which the soul also receives images from the sensory impulses from the outside (cf. the two types of imprint from the Theaetetus). The discursive study of these projections prepares the soul for the intuitive contemplation of the Forms.

\section{Porphyry Sent. 16 revisited}

\subsection{The Scope of Sentence 16}

As we noted in the introduction, Pépin assumed that Sentence 16 is primarily about sensation, which Porphyry here discusses in relation to intellection. Following the first lines of the Sentence, however, it seems more precise to say that it is about the relation of soul to its reason-principles or logoi. Soul possesses these at all times, yet only uses them actively in two different cases. In the case of sense-perception, it uses them in order to judge and interpret incoming sensory data. ${ }^{30}$ In the case of philosophical reflection, soul uses them as images of the Forms, which allow it to study the Forms in a discursive fashion. This use of the logoi helps the soul to ascend to the direct, intuitive contemplation of the Forms at the level of Intellect ("becomes in intellections").

It should be evident by now that Porphyry's statement about soul's double activity regarding its logoi summarizes more lengthy discussions about the same topic in Plotinus that we have analyzed above. As we have seen, Plotinus discussion is inspired by the simile of the waxen block from Plato's Theaetetus. Elsewhere, Plotinus makes use of the related simile of the aviary when he describes the activation of the logoi-both in the case of the sense-perception and philosophical reflection-as the "taking in hand" ( $\pi \rho \circ \chi \varepsilon i \rho i \sigma i \varsigma)$ of these reason-principles: the soul projects as it were these logoi in its image-making faculty. Porphyry here uses the term

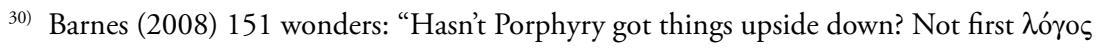
and then perception, but first perception and then $\lambda$ ó ${ }^{\circ} \varsigma$." He then argues that in order to perceive a llama as a llama we first need to have a notion of a llama. But note that in a way for Porphyry and Plotinus the order is indeed first perception, then $\lambda$ ó something. Next, when we want to determine what it is that we see, we activate the rele-

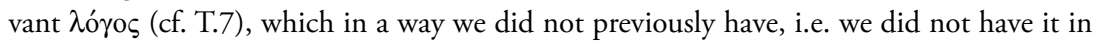
hand.
} 
in a similar way in the case of the activation of the logoi in the case of sense-perception. In this context, the intermediate preceding sentence about memory appears relevant. As we shall see shortly (T.10), Plotinus understands the reception of an image of a Form in the image-making faculty of the soul in terms of the Platonic doctrine of the anamnesis of the Forms. In Sent. 15 Porphyry makes a similar point: memory is not the (passive) "preservation of representations" (cf. T.8 above), but consists in (active) projection, $\pi \rho \circ \beta \circ \lambda \eta{ }^{31}$ As I shall argue below, Sentence 16 is ultimately about the activation of this memory by studying the logoi as a preparation for intuitive intellection. The case of sense-perception is only discussed to elucidate this other activity concerning the logoi .

\subsection{No Intellections Without Mental Images}

Now that we have dealt with the expression $\pi \rho 0 \chi \varepsilon i \rho i ́ r 1 s$, let us move on to the second issue concerning Sentence 16: how should we understand Porphyry's remark that intellections (vónбeıs) do not occur without imaging $(\varphi \alpha v \tau \alpha \sigma i \alpha)$ ? Does Porphyry here side with Aristotle against Plotinus, as Schwyzer believed? We cannot, of course, exclude as a matter of principle the possibility that Porphyry went his own way. In the present case this seems unlikely, though. On the one hand, what Porphyry has said so far in Sentence 16 is in line with Plotinus' philosophy. On the other hand, the analogy which is presented as the conclusion of the reflection on the relation between intellection and imaging is entirely consistent with Plotinus' discussions of that matter, as I shall now first demonstrate.

In Enn. V 3 [49] 2-3, a passage we have dwelt on above, Plotinus contrasts the way in which soul functions to that of Intellect. Intellect and soul may contemplate the same things, yet they do so in different ways. While Intellect thinks itself, i.e. thinks itself by contemplating (voeiv) the Forms which are in Intellect all at once, soul reasons $\left(\lambda \circ \gamma_{i} \zeta_{\varepsilon \sigma \sigma} \theta \alpha \mathrm{l}\right)$, i.e.

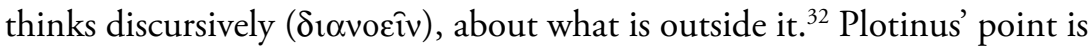
that soul does not have intellection properly speaking, but that it rather has some sort of experience of it as something external to it. He compares the relation of soul to Intellect to that of soul to sense-perception. Both intellection and sense-perception take place outside the soul. Rather than

31) On Sentence 15, see further the informative notes in Brisson (2005) 427-430.

32) Enn. V 3 [49] 3, 12-21. 
having intellection or sense-perception, soul perceives these as activities that go on outside itself. Plotinus puts it as follows:

[T.9] The activities of Intellect are from above in the same way that those of sense-perception are from below; we are this, the principal part of the soul in the middle between two powers, a worse and a better, the worse that of sense-perception, the better that of Intellect (Enn. V 3 [49] 3, 36-40; trans. Armstrong).

In the light of the previous discussion, it may come as somewhat as a surprise to learn that sense-perception is not a power of the soul but of something inferior to it. We should note, though, that Plotinus distinguishes between two types of sense-perception, one of the soul and another of the

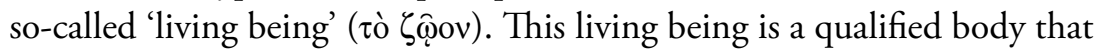
is illuminated by soul and that does the actual sensing. ${ }^{33}$ The $\alpha i \sigma \theta \eta \sigma 1 s$ (sense-perception) of this living being should be distinguished from that of soul. As we have seen, the sense-perception of the soul consists in an activity, that of judgment, whereas the sense-perception of the 'living being' consists in receiving the sensory data through the affected sense organs. The 'living being' translates these data into the imprints ( $\tau$ ivor) that are subsequently judged by the soul. ${ }^{34}$

Soul apprehends the activities of the superior Intellect in a way similar to those of the inferior living being. Plotinus' discussion of memory as

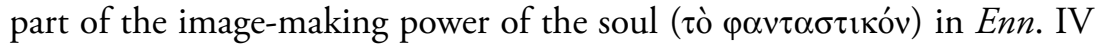
3 [27] 30 is instructive. It merits quoting this text in full:

[T.10] Perhaps the reception into the image-making power (

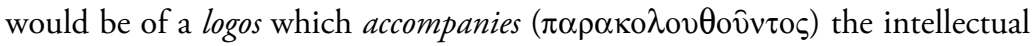
thought $(v o \eta \mu \alpha)$. The intellectual thought is without parts and has not, so to speak, come out in the open, but remains unobserved within, but the logos unfolds its content and brings it out of the intellectual thought into the image-making power, and so shows the intellectual thought as if in a mirror,

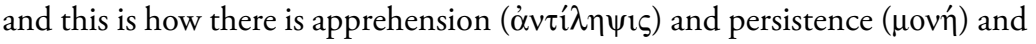

33) Cf. Plotinus Enn. I 1 [53] 7, 1-6.

34) Cf. Plotinus Enn. I 1 [53] 7, 9-14. On the two forms of sense-perception, cf. Emilsson (1988) 114-121 (followed by Marzolo (2006) 135-136 in his commentary ad loc.); Aubry (2004) 208-214. 
memory $(\mu v \eta \mu \eta)^{35}$ of it. The intellectual thought is one thing and the apprehension of it another, and we are always intellectually active but not always apprehend our activity; and this is because that which receives it does not only receive intellectual thoughts, but also on its other side, perceptions (Enn. IV 3 [27] 30, 5-16; trans. Armstrong slightly adapted).

We find here once again the same pattern that we have discussed above. Intellect contemplates the Forms in its proper, non-discursive fashion. From Intellect there emanates a discursive version of it, the $\lambda$ óros, which manifests itself as mental images. ${ }^{36}$ Plotinus' point here is not that intellection requires mental images, as Aristotle would have it. His point is that the active Intellect, through the intermediary of logos, produces mental images in the soul as some sort of by-product of its own intellectual activity. For this reason, Plotinus here describes this emanation of logos from Intellect into the phantasia in terms of a logos accompanying ( $\left.\pi \alpha \rho \alpha \kappa o \lambda o v \theta \varepsilon^{\prime} \omega\right)$ Intellect. Note, finally, that Plotinus here once again presents soul's apprehension of the activities of Intellect as analogous to its apprehension of perceptions, i.e. as activities that go on outside soul itself. Thus, when Porphyry in Sentence 16 describes the imprint in the soul as analogous to the mental image in that they are both by-products $(\pi \alpha \rho \alpha \kappa o \lambda o v i \eta \eta \mu \alpha$; $\dot{\varepsilon} \pi$ ó $\varepsilon v o v)$ of activities that go on outside the soul, he follows closely in the footsteps of Plotinus. ${ }^{37}$

If this is the point of the analogy, it seems unlikely that in the previous sentence Porphyry indeed meant that intellections require mental images. Yet this is at first sight precisely what he seems to suggest when he compares the intellections to sense-perceptions in the case of the living being: without affections of the sensory organs no sense-perceptions, without mental images no intellections. We should keep in mind, though, that Sentence 16 discusses sense-perception and intellection from the perspective of soul. The issue is how the soul produces sense-perceptions and

\footnotetext{
35) A reference to the etymology of $\mu v \eta$ pn from $\mu$ oví in Crat. 437b2-4, as D’Ancona (2007) 90 n. 45 points out.

36) Cf. the discussion of this text by Emilsson (1988) 135-136, who in his discussion highlights the difference between Form and logos, and D'Ancona (2007) 86-89.

37) Thus, contrary what Dillon's translation of Sent. 16 suggests (“(external) imprints"), I do not understand the imprint ( $\tau \dot{\tau} \pi \mathrm{\circ} \varsigma$ ) as the affections of the sensory organs in the case of the living being, but as the result that this has on the soul.
} 
"becomes in intellections". Just as the affections of the sensory organs alert the living being that something goes on in the outside world, the mental images make us aware that there is intellectual activity going on in a higher realm. ${ }^{38}$ Both Plotinus and Porphyry understand this awareness of projections of Nous in terms of memory and as acting on or listening to our reason-principles. It may be that Porphyry chose a formulation that echoes Aristotle's claim that "the soul never thinks without a mental image", because-contrary to Plotinus who was quite happy to criticize the Stagirite- he wished to harmonize Aristotle with Platonic thought. However, there is little 'Unplotinisches' about what he meant by it.

In T.9 and T.10 Plotinus compares soul's apprehension of intellections to its apprehension of sense-perception both in order to explain how the former comes about and in order to turn the attention of his readers away from the world of the senses towards the recollection of the intelligible. Sentences 16 on soul's activities regarding the logoi in combination with Sentence 15 on memory serve the same purpose. In this way they are indeed

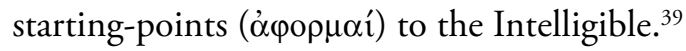

\section{Bibliography}

Armstrong, A.H. 1966-1989. Plotinus, 7 vol. Loeb Classical Library. Cambridge, Massachusetts: Harvard University Press.

Aubry, G. 2004. Plotin Traité 53 (I,1). Paris: Les Éditions du Cerf.

Barnes, J. 2008. “There Was an Old Person from Tyre' Critical Notice of George Karamanolis and Anne Sheppard (eds.), Studies on Porphyry", Rhizai 5, 127-151.

\footnotetext{
38) The referee argues for the following interpretation based on the construction of the

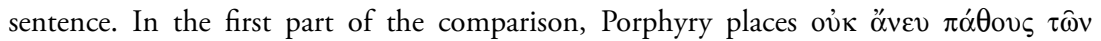

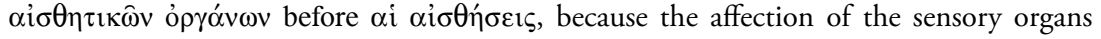
necessarily precedes the sense-perception. In the second part of the comparison, he places

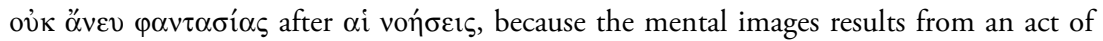
intellection, i.e. the investigation of a logos. For this reason, Porphyry describes the affection as a $\pi \alpha \rho \alpha \kappa о \lambda о v i \theta \eta \mu \alpha$ of the sense-perception of the living being, whereas the mental images "follows" (غ̇ ó $\mu \varepsilon v o v)$ the intellection. I fail to see how, on this reading, the fact that the imprint is an accompaniment is analogous to the fact that the mental images is a consequence of intellection.

39) For this translation of the title of the work, see Dillon in Brisson (2005) 795 n.1, cf. the observations about the $\alpha \varphi o p \mu \alpha i$ as an "exercise spirituel” by R. Goulet in Brisson (2005) $11-16$
} 
Blumenthal, H.J. 1989. 'Plotinus and Proclus on the Criterion of Truth', in: P. Huby, and G. Neal (eds.), The Criterion of Truth: Essays in Honour of George Kerferd. Liverpool: Liverpool University Press, 257-280. Reprinted in: Blumenthal H.J. 1993. Soul and Intellect: Studies in Plotinus and Later Neoplatonism, Essay X. Aldershot: Variorum.

Bonazzi, M. 2005. 'Plotino, il Teeteto, gli Stoici. Alcune osservazioni intorno alla percezione e alla conoscenza', in: Chiaradonna (2005) 202-222.

Brisson, L. 1999. 'Logos et Logoi chez Plotin: leur nature et leur role'. Les cahiers philosophiques de Strasbourg 8, 87-108.

— (ed.) 2005. Porphyre Sentences: Études d'introduction, texte grec et traduction française, commentaire, 2 vol. Paris: J. Vrin.

Chiaradonna, R. (ed.) 2005. Studi sull'Anima in Plotino. Napoli: Bibliopolis.

Cornford, F.M. 1935. Plato's Theory of Knowledge. The Theaetetus and the Sophist of Plato translated with a Running Commentary. London: Routledge \& Kegan Paul.

D’Ancona, C. 2007. 'Plotini: memoria di eventi e anamnesi di intelligibili', in: M.M. Sassi (ed.), Tracce nella mente: Teorie della memoria da Platone e i moderni. Pisa: Edizioni della Normale.

Emilsson, E.K. 1988. Plotinus on Sense-perception: A Philosophical Study. Cambridge: Cambridge University Press.

Karamanolis, G. \& Sheppard, A. (eds) 2007. Studies on Porphyry, BICS Suppl. 98. London: Institute of Classical Studies.

Lautner, P. 2007. 'Perception and Self-knowledge: Interpreting Fr. 264 Smith', in: Karamanolis \& Sheppard (2007) 77-90.

Levett, M.J. 1990. 'Translation of Plato's Theaetetus', in: M. Burnyeat, The Theaetetus of Plato. Indianapolis: Hackett Publishing Company, 257-351.

Marzolo, C. 2006. Plotino. Che cos'è l'essere vivente e che cos'è l'uomo? I 1 [53]: Introduzione, testo greco, traduzione e commento. Pisa: Pisa University Press.

Schwyzer, H.-D. 1974. 'Plotinisches und Unplotinisches in den Apopuxí des Porphyrios', in: Plotino e il Neoplatonismo in Oriente e in Occidente. Roma: Academia Nazionale dei Lincei, 221-252.

Sheppard, A. 2007. 'Porphyry's Views on Phantasia', in: Karamanolis \& Sheppard (2007) 71-76.

Sorabji, R. 2004. The Philosophy of the Commentators 200-600 AD: A Sourcebook. Volume 1: Psychology (with Ethics and Religion). London: Duckworth. 